ORIGINAL PAPER

Jean Herman - Pierre van der Bruggen - Immanuel F. Luescher - Susanna Mandruzzato - Pedro Romero • Joëlle Thonnard · Katharina Fleischhauer • Thierry Boon - Pierre G. Coulie

\title{
A peptide encoded by the human MAGE3 gene and presented by HLA-B44 induces cytolytic $T$ lymphocytes that recognize tumor cells expressing MAGE3
}

\begin{abstract}
The human $M A G E 3$ gene is expressed in a significant proportion of tumors of various histological types, but is silent in normal adult tissues other than testis and placenta. Antigens encoded by MAGE3 may therefore be useful targets for specific antitumor immunization. Two antigenic peptides encoded by the MAGE3 gene have been reported previously. One is presented to cytolytic T lymphocytes (CTL) by HLA-A1, the other by HLA-A2 molecules. Here we show that MAGE3 also codes for a peptide that is presented to CTL by HLA-B44. MAGE3 peptides containing the HLA-B44 peptide binding motif were synthesized. Peptide MEVDPIGHLY, which showed the strongest binding to HLA-B44, was used to stimulate blood T lymphocytes from normal HLA-B44 donors. CTL clones were obtained that recognized not only HLA-B44 cells sensitized with the peptide, but also HLA-B44 tumor cell lines expressing MAGE3. The proportion of metastatic melanomas expressing the MAGE3/HLA-B44 antigen should amount to approximately $17 \%$ in the Caucasian population, since $24 \%$ of individuals carry the HLA-B44 allele and $76 \%$ of these tumors express MAGE3.
\end{abstract}

J. Herman • P. van der Bruggen $\cdot$ S. Mandruzzato $\cdot$ T. Boon $\cdot$ P. G. Coulie (『)

Ludwig Institute for Cancer Research, 74 avenue Hippocrate, UCL

74.59 B-1200 Brussels, Belgium and Cellular Genetics Unit, Université Catholique de Louvain, Brussels, Belgium

I. F. Luescher • P. Romero

Ludwig Institute for Cancer Research, Lausanne Branch, and University of Lausanne, 1066 Epalinges, Switzerland

J. Thonnard

Laboratoire de Biologie Moléculaire Clinique, Cliniques Universitaires Saint Luc, Brussels, Belgium

K. Fleischhauer

Laboratory of Experimental Hematology, DIBIT, Istituto Scientifico H. S. Raffaele, 20132 Milano, Italy

\section{Introduction}

Cytolytic T lymphocytes (CTL) directed against human tumor cells can be obtained by the culture of blood lymphocytes of cancer patients with irradiated autologous tumor cells (Boon et al. 1994). Anti-tumor CTL clones can then be derived from the responder T-cell populations. Several genes coding for antigens recognized by such CTL clones have been identified. The MAGEl gene codes for an antigenic peptide, MAGE1.A1, recognized on HLA-A1 by autologous CTL directed against a melanoma cell line derived from patient MZ2 (Traversari et al. 1992; van der Bruggen et al. 1991). MAGE1 belongs to a family of closely related genes clustered within two distinct regions on chromosome X. MAGE1 to -12 are located in the $X q 26$ region, while an additional member has been identified in the Xp21.3 region (De Plaen et al. 1994; Muscatelli et al. 1995). The MAGE gene family is silent in normal adult tissues, with the exception of testis and placenta (De Plaen et al. 1994). MAGE1, 2, 3, 4, 6, and 12 are expressed in a significant proportion of tumors of various histological types, including melanomas, lung tumors, head and neck tumors, sarcomas, and breast tumors (Brasseur et al. 1992; Brasseur et al. 1995; De Plaen et al. 1994; Weynants et al. 1994). The sequences of the proteins encoded by $M A G E 2$, 3, 4, 6 and 12 display $57 \%$ to $77 \%$ identity to that of MAGE1 (De Plaen et al. 1994). The function of these proteins is unknown at present. The MAGE3 gene, which is expressed by $76 \%$ of metastatic melanoma samples (Brasseur et al. 1995), was found to code for another peptide, MAGE3.A1, also presented by HLA-A1 and recognized by anti-tumor CTL of patient MZ2 (Gaugler et al. 1994).

Because the proteins encoded by $M A G E$ genes contain more than 300 amino acids, they are expected to contain several peptides that can associate with various HLA molecules and hence may provide many potential target antigens for specific anti-tumor T-cell responses. One method of identifying these new tumor antigens starts with the examination of $M A G E$ sequences for known 
HLA-binding peptide motifs. Potentially relevant peptides deduced from the gene sequence can then be synthesized and tested for their ability to bind to the relevant HLA molecule. The best binders are used to stimulate $\mathrm{T}$ cells in vitro in order to obtain CTL that recognize the relevant peptide-HLA complexes. It should then be ascertained that these CTL recognize tumor cells expressing the relevant HLA and MAGE gene. With lymphocytes from normal individuals, this strategy led to an independent identification of the MAGE3.A1 antigenic peptide (Celis et al. 1994), and more recently to the identification of a MAGE3 antigen presented by HLA-A2 (van der Bruggen et al. 1994). Here we report that by using this strategy we were able to derive HLA-B44-restricted anti-tumor CTL that recognize a $M A G E 3$ peptide.

\section{Materials and methods}

\section{Cell lines}

Tumor cell lines and Epstein-Barr virus (EBV)-transformed B cell lines were cultured in Iscove's medium (Gibco, Grand Island, NY) supplemented with $10 \%$ fetal calf serum (FCS), L-arginine $(116 \mathrm{mg} / \mathrm{L})$, Lasparagine $(36 \mathrm{mg} / \mathrm{L})$, and L-glutamine $(216 \mathrm{mg} / \mathrm{L})$. Cells of the MHC class I-negative lymphoblastoid cell line C1R (Storkus et al. 1987), transfected either with a cDNA clone encoding $H L A-B * 4402$ or with an $H L A-B * 4403$ genomic clone (Fleischhauer et al. 1994; Fleischhauer et al. 1990), were grown in RPMI-1640 medium (Gibco) supplemented with $10 \%$ FCS.

In contrast to all the other EBV-transformed B cells that we tested, $\mathrm{C} 1 \mathrm{R}$ cells express the MAGE3 gene. The C1R-B44 transfectants were lysed by the anti-MAGE3B44 CTL clones described below.

\section{Synthetic peptides}

Peptides were synthesized on solid phase using Fmoc for transient $\mathrm{NH}_{2}$-terminal protection as described by Atherton and co-workers (1981) and were characterized by mass spectrometry. All peptides were $>90 \%$ pure as indicated by analytical HPLC. Lyophilized peptides were dissolved in DMSO and diluted in either PBS or acetic acid $(10 \mathrm{mM})$, and stored at $-80^{\circ} \mathrm{C}$.

\section{Cytokines}

Human recombinant IL-2 and IL-4 were donated by Biogen (Geneva, Switzerland) and R. Devos (Roche Research Center, Gent, Belgium), respectively. One unit $/ \mathrm{ml}$ of IL-2 gives $50 \%$ maximal proliferation of CTLL-2 cells. One unit/ml of IL-4 gives $50 \%$ maximal proliferation of human $\mathrm{T}$ cells previously activated with phytohemagglutinin A. Human recombinant IL-6 was obtained from J. Van Snick (our laboratory). One unit $/ \mathrm{ml}$ of IL-6 gives 50\% maximal proliferation of 7TD1 cells. Human recombinant IL-7 was purchased from R\&D Systems Europe (Abingdon, Oxon, U. K). Human recombinant IL-12 (specific activity: $5.26 \times 10^{6}$ units $/ \mathrm{mg}$ ) was donated by S. Wolf (Genetics Institute, Cambridge, Massachussets, USA). Human recombinant GM-CSF was purchased from Sandoz (Sandoz Pharma, Basel, Switzerland).

\section{Competition assay}

The C1R-B*4402 or C1R-B*4403 cells were ${ }^{51}$ chromium-labeled for $1 \mathrm{~h}$ at $37^{\circ} \mathrm{C}$ in the presence of human-specific class I MHC monoclonal antibody $(\mathrm{mAb}) \mathrm{W} 6 / 32(30 \%$ [v/v] of culture medium of the hybridoma cells) and washed three times. The labeled cells (1000 cells in $80 \mu \mathrm{l})$ were incubated in V-bottom microwells for $30 \mathrm{~min}$ at $20^{\circ} \mathrm{C}$ in serum-free medium X-VIVO 10 (Wittaker Bioproducts, Walkersville, MD) with various concentrations of competitor peptides. Antigenic peptide EEKLIVVAF was then added in X-VIVO 10 medium $(40 \mu \mathrm{l})$ at a final concentration of $50 \mathrm{ng} / \mathrm{ml}$ for C1R-B $* 4402$ cells and of $160 \mathrm{ng} /$ $\mathrm{ml}$ for C1R-B*4403 cells. Cells were incubated for $30 \mathrm{~min}$ at $20^{\circ} \mathrm{C}$ and washed in Iscove's medium containing $2 \%$ FCS. CTL clone LB33CTL-159/5 (20000 cells in $150 \mu \mathrm{l}$; Coulie et al. 1995), which recognizes peptide EEKLIVVAF in the context of both HLA-B*4402 and HLA-B*4403 targets, was added in Iscove's medium supplemented with $10 \%$ human serum. Chromium release was measured after $3 \mathrm{~h}$. Percentage control lysis was calculated as $100 \times$ [(\%lysis with competitor-background lysis)/(\%lysis without competitor-background lysis)]. Background lysis is the \% lysis of target cells in the absence of peptides and was $1 \%$ and $3 \%$ for C1R-B*4402 and C1R-B*4403, respectively. Lysis without competitor peptides was $58 \%$ for C1R$B * 4402$ and $72 \%$ for C1R-B*4403. Peptide EEKLIVVAF is a variant of peptide EEKLIVVLF which is presented to CTL $159 / 5$ by the melanoma cells of patient LB33 (Coulie et al. 1995). The variant peptide was better recognized on HLA-B*4403 than the original peptide. No difference was observed on HLA-B*4402.

\section{Induction of CTL}

Peripheral blood mononuclear cells (PBMC) were isolated using Lymphoprep (Nycomed Pharma, Oslo, Norway) density gradient centrifugation. T lymphocytes were purified by rosetting with 2aminoethylisothiouronium bromide hydrobromide-treated sheep erythrocytes (Mikamo 1988), and labeled with an CD8-specific mAb coupled to magnetic microbeads (Miltenyi Biotech, Germany). CD8+ cells were sorted by passage through a magnet and subsequently frozen. The non-rosetting PBMC were left to adhere for $2 \mathrm{~h}$ at $37^{\circ} \mathrm{C}$ on Tissue Culture wells (NUNC Multidish 6, Roskilde, Denmark). Non-adherent cells were discarded, and adherent cells were cultured for 7 days in the presence of IL-4 (50 units/ml) and GM-CSF (100 ng/ $\mathrm{ml}$ ) in RPMI-1640 medium $+10 \%$ FCS. The resulting cell populations were analyzed for the expression of CD11 c and CD14 surface antigens, using flow cytometry. For donor LB816 most of the cells were CD11 $\mathrm{c}^{+} \mathrm{CD} 14^{+}$, whereas for donor LB822 most of them were CD11 $\mathrm{c}^{+}$ CD14-. These antigen-presenting cells $\left(5 \times 10^{5}\right.$ to $\left.10^{6}\right)$ were incubated in $2 \mathrm{ml}$ wells (NUNC) for $4 \mathrm{~h}$ at $37^{\circ} \mathrm{C}$ in $400 \mu \mathrm{l}$ Iscove's medium supplemented with human $\beta_{2}$-microglobulin ( $\beta_{2} \mathrm{~m}, 2.5 \mu \mathrm{g} / \mathrm{ml}$, Sigma) and peptide MEVDPIGHLY $(50 \mu \mathrm{g} / \mathrm{ml})$. The peptide-pulsed cells were then irradiated at $50 \mathrm{~Gy}$ and washed. Autologous CD8+ T cells $\left(2 \times 10^{6}\right)$ in culture medium [(Iscove's medium $+10 \%$ human serum, L-arginine, L-asparagine, L-glutamine, and 2-mercaptoethanol (0,05 mM)] supplemented with IL-6 (1000 units/ml) and IL-12 (5 ng/ml) were added. On day 7 , the lymphocytes were restimulated with adherent autologous PBMC pulsed with the peptide. PBMC $\left(5 \times 10^{6}\right)$ were left to adhere for $2 \mathrm{~h}$ at $37^{\circ} \mathrm{C}$ in $400 \mu \mathrm{l}$ Iscove's medium containing $\beta_{2} \mathrm{~m}$ and peptide MEVDPIGHLY as before. Peptide-pulsed adherent cells were irradiated and washed. Responder lymphocytes in culture medium supplemented with IL-2 (10 units/ml) and IL-7 $(5 \mathrm{ng} / \mathrm{ml})$ were added. On day 14, lymphocytes were restimulated with autologous PBMC pulsed with the peptide. PBMC $\left(2 \times 10^{7} / \mathrm{ml}\right)$ were incubated for $2 \mathrm{~h}$ at $20^{\circ} \mathrm{C}$ in Iscove's medium with $\beta_{2} \mathrm{~m}$ and peptide MEVDPIGHLY as before, irradiated, washed, and resuspended at $2 \times 106 / \mathrm{ml}$ in culture medium supplemented with IL-2 and IL-7 as before. These stimulator cells $\left(2 \times 10^{6}\right)$ were added to each well containing the responder cells.

On day 21 , lymphocytes from cultures showing peptide-specific lytic activity were cloned by limiting dilution in culture medium supplemented with IL-2 (50 units/ml) and IL-4 (5 units/ml). LB816 clones were stimulated with irradiated C1R-B*4402 cells (150 Gy, 8000 cells/well) that had been incubated for $1 \mathrm{~h}$ at $20^{\circ} \mathrm{C}$ with peptide MEVDPIGHLY $(1 \mu \mathrm{g} / \mathrm{ml})$ and washed. LB822 clones were stimulated with irradiated MZ2-MEL tumor cells (100 Gy, HLA-B*4403, MAGE$3^{+}, 8000$ cells/well). Irradiated allogeneic LG2-EBV cells (100 Gy, 20000 cells/well) were added as feeder cells to the clones. The microcultures were likewise stimulated each week. After 4 weeks, CTL clones LB816-340/1 and LB822-346/8 were stimulated each week in $2 \mathrm{ml}$ wells with $2 \times 10^{5}$ irradiated C1R-B*4402 or C1R-B*4403 cells that had been incubated for $1 \mathrm{~h}$ at $20^{\circ} \mathrm{C}$ with peptide MEVDPIGHLY 

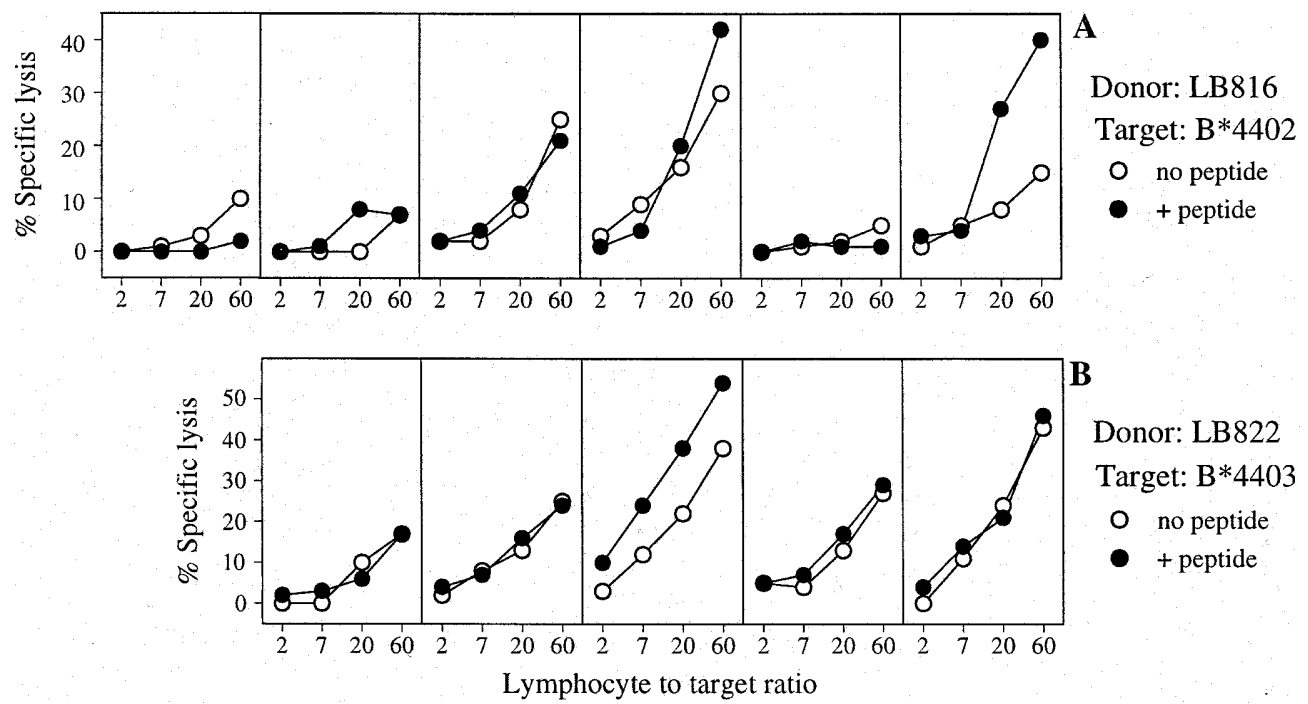

$(1 \mu \mathrm{g} / \mathrm{ml})$ and washed, and with $10^{6}$ irradiated LG2-EBV cells, all in culture medium supplemented with IL-2 and IL-4 as before.

\section{Transfection and CTL stimulation assay}

COS-7 cells (15000/well) were co-transfected, using the DEAEdextran-chloroquine method (Seed and Aruffo 1987), with $50 \mathrm{ng}$ of plasmid pcDNAI/Amp containing the cDNA of MAGE3 and either $50 \mathrm{ng}$ of plasmid pcDNAI/Amp containing the cDNA of HLA-B*4403 or $50 \mathrm{ng}$ of plasmid pcDNA3 containing the cDNA of HLA-B*4402. NA8-MEL melanoma cells (HLA-A1, A2, B12, B40, MAGE3-, 30000 cells/well) were co-transfected with $100 \mathrm{ng}$ of plasmid pcDNAI/AmpMAGE3 and either $100 \mathrm{ng}$ of plasmid pcDNA3-HLA-B*4402 or $100 \mathrm{ng}$ of plasmid pcDNAI/Amp-HLA-B*4403, using LIPOFECTAMINE (Gibco BRL). After $36 \mathrm{~h}$ of incubation at $37^{\circ} \mathrm{C}$, the COS-7 and NA8-MEL transfectants were tested for their ability to stimulate the production of TNF by CTL (Lehmann et al. 1995). In brief, 3000 CTL were added in $100 \mu \mathrm{l}$ of Iscove's medium supplemented with $10 \%$ human serum and IL-2 (25 units/ml). After $20 \mathrm{~h}$, the supernatant was collected and its TNF content determined by testing its cytotoxicity on WEHI-164c13 cells (Espevik and Nissen-Meyer 1986).

\section{Chromium-release assay}

Target cells shown in Figures 1 and 2 were labeled with ${ }^{51}$ chromium as described above, and washed. The labeled target cells (1000 cells/well) were incubated with the effector cells in the absence or presence of peptide MEVDPIGHLY $(1 \mu \mathrm{g} / \mathrm{ml})$ (Fig. 1). Alternatively, the labeled target cells (1000 cells/well) were first incubated in V-bottom microwells for $30 \mathrm{~min}$ at $20^{\circ} \mathrm{C}$ with various concentrations of the peptide in serum-free medium X-VIVO 10 and washed in Iscove's medium containing 2\% FCS, before addition of CTL (10000 cells/well) in medium containing $10 \%$ human serum (Fig. 2).

\section{HLA-B44 subtyping}

Part of exon 3 of the HLA-B44 allele was amplified from genomic DNA with oligonucleotides BX3S1 (5'-GGGTCCAGGGTCTCACATCA-3') and BX3R1 (5'-CCAGGTATCTGCGGAGCG-3'). The amplified 254 bp fragment of exon 3 was digested with $R s a \mathrm{I}, P v u \mathrm{II}$, and $B s a \mathrm{AI}$ to distinguish between the subtypes $B^{*} 4402,-03,-04$, and -05 .
Fig. 1 Lytic activities of $\mathrm{CD}^{+}$blood lymphocytes stimulated with peptide MAGE-3.B44. Two series, of six and five cultures, were set up with $2 \times 10^{6}$ CD8 blood lymphocytes from normal donors LB816 (HLA-B*4402) and LB822 (HLA-B*4403), respectively. These lymphocytes were stimulated with autologous macrophages and dendritic cells incubated with peptide MAGE3.B44. The responder cells were restimulated every week by autologous cells incubated with peptide MAGE3.B44. On day 20, lytic activities were tested against EBVtransformed B cells expressing the same HLA-B44 subtype as the donor, namely LB33-EBV (HLA-B*4402) or LG2-EBV (HLA$B * 4403)$. The indicated numbers of effector cells were incubated for 45 min with unlabeled K562 target cells (50000 cells/well) in order to inhibit lysis by NK-like effectors. ${ }^{51}$ chromium-labeled target cells (1000 cells/well), incubated with $1 \mu \mathrm{M}$ peptide MAGE-3.B44 (O), or without it $(\bigcirc)$, were added and chromium release was measured after $4 \mathrm{~h}$

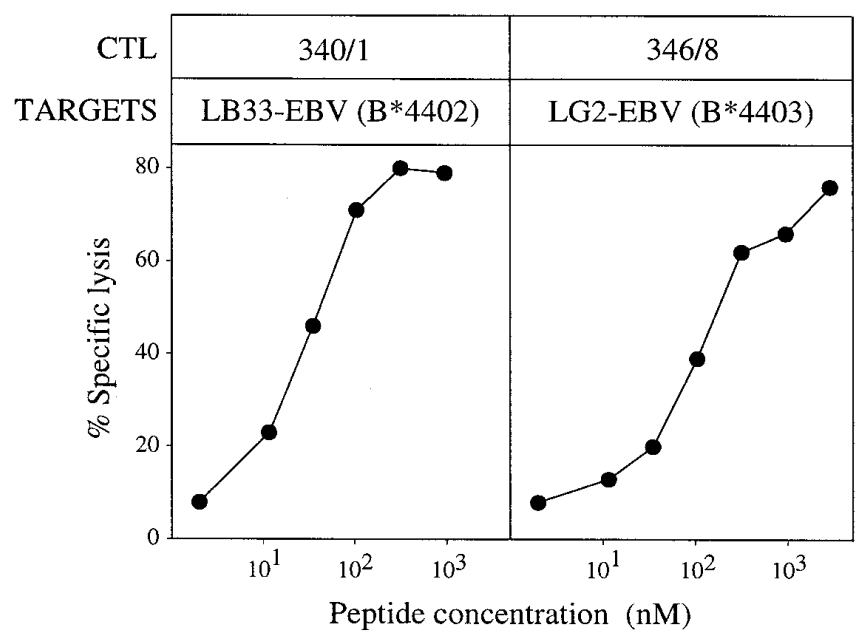

Fig. 2 Recognition of peptide MAGE3.B44 by HLA-B*4402 or HLA-B*4403-restricted CTL clones. CTL clones (10000 cells/well) were added to the labeled lymphoblastoid B cells (1000 cells/well), which had been incubated for $30 \mathrm{~min}$ at $20^{\circ} \mathrm{C}$ in serum-free medium with the indicated concentrations of peptide MAGE3.B44 and washed. Chromium release was measured after $4 \mathrm{~h}$ 


\section{Results and Discussion}

HLA-B44 is expressed in $22 \%-24 \%$ of Caucasians (Imanishi et al. 1991; Lee 1990). Five HLA-B44 alleles have been identified: $H L A-B^{*} 4402,3,4,5$, and 6 (Fleischhauer et al. 1991; Petersdorf et al. 1994; Yao et al. 1994, $1995 \mathrm{a}$, $1995 \mathrm{~b})$. The $H L A-B * 4402$ and $B * 4403$ alleles are expressed by $61 \%$ and $36 \%$ of HLA-B44 Caucasians, respectively (Yao et al. 1995 a). They differ only at position 156, located in the middle of the $\alpha 2$ helix and extending into the peptide binding site: it is occupied by Asp in $H L A-B * 4402$ and by Leu in $H L A-B * 4403$ (Fleischhauer et al. 1991). Bone marrow allograft rejection and graft versus host disease have been observed between donors and recipients differing with respect to these two subtypes of HLA-B44, suggesting that there might be differences in peptide presentation by the two subtypes (Fleischhauer et al. 1990; Keever et al. 1994). Therefore, in our search for a MAGE3 peptide recognized on HLA-B44 we examined both the $H L A-B * 4402$ and $H L A-B * 4403$ subtypes.

Identification of MAGE3-encoded peptides binding to HLAB44

Antigenic peptides recognized by T lymphocytes on HLAB44, or eluted from HLA-B44 molecules, often contain Glu in position 2 and Tyr or Phe in position 9 or 10 (Brichard et al. 1995; Buseyne et al. 1993; Coulie et al. 1995; DiBrino et al. 1995; Fleischhauer et al. 1994; Khanna et al. 1992; Kita et al. 1993). There are four peptide sequences with this binding motif in the MAGE3 sequence (Table 1). These peptides were synthesized, and their ability to bind to HLAB44 molecules was tested in a competition assay. The MHC

Table 1 Binding to HLA-B44 of peptides encoded by MAGE3. The ability of the peptides to compete with a standard peptide for binding to HLA-B*4402 and HLA-B*4403 molecules was measured with CTL clone $159 / 5$, which recognizes peptide EEKLIVVAF on C1R-B*4402 or C1R-B*4403 cells. Specific lyses obtained with this peptide alone were $58 \%$ and $72 \%$ for $\mathrm{C} 1 \mathrm{R}-\mathrm{B} * 4402$ and $\mathrm{C} 1 \mathrm{R}-\mathrm{B} * 4403$, respectively. Control peptides included tyrosinase peptide SEIWRDIDF, which was shown to bind to both HLA-B44 subtypes (Brichard et al. 1995), and EBNA3A peptide FLRGRAYGL, which binds to HLA-B8 (Burrows et al. 1990)

\begin{tabular}{lcc}
\hline Competitor peptides & $\begin{array}{l}\text { Concentration }(\mu \mathrm{M}) \text { of peptide } \\
\text { resulting in a 50\% inhibition of the } \\
\text { lysis of C1R-B44 cells sensitized } \\
\text { with peptide EEKLIVVAF }\end{array}$ \\
\hline & C1R-B*4402 & C1R-B*4403 \\
\hline MAGE3 peptides & & \\
QEEEGPSTF (90-98) & 60 & 15 \\
MEVDPIGHLY (167-176) & 2 & 1 \\
WEELSVLEVF (222-231) & 80 & 7 \\
EELSVLEVF (223-231) & 20 & 5 \\
Control peptides & & $<1$ \\
SEIWRDIDF (Tyrosinase) & 1 & $>100$ \\
FLRGRAYGL (EBNA3A) & $>100$ & \\
\hline
\end{tabular}

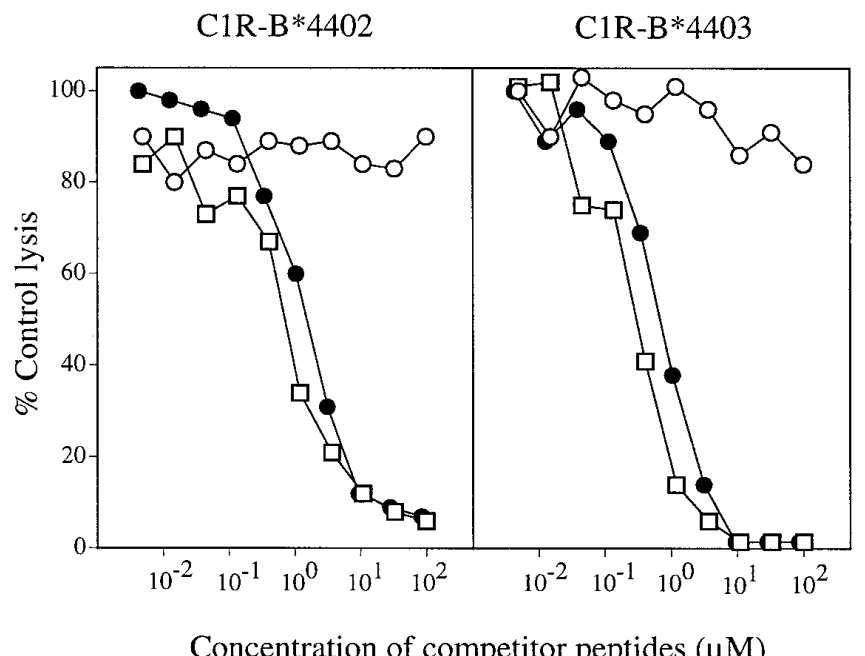

Fig. 3 Binding of peptide MEVDPIGHLY to HLA-B44 molecules measured in a competition assay. The data were obtained in the experimental conditions described in Table 1 . Competitor peptides included the MAGE3.B44 peptide MEVDPIGHLY (O), the tyrosinase.B44 peptide SEIWRDIDF ( $\square$ ) as positive control, and the EBNA3A peptide FLRGRAYGL $(O)$ as negative control

class I-negative $\mathrm{C} 1 \mathrm{R}$ cells were transfected with either the $H L A-B * 4402$ or the $H L A-B * 4403$ gene. The C1R-B44 cells were incubated with increasing concentrations of different $M A G E 3$ peptides and with a constant concentration of peptide EEKLIVVAF, which is recognized on HLA-B44 by the anti-melanoma cytolytic T-cell (CTL) clone LB33CTL-159/5 (Coulie et al. 1995). All four MAGE3 peptides inhibited lysis of C1R-B44 cells, indicating that they bound to HLA-B44 molecules (Table 1). Peptide MEVDPIGHLY was the best binder on both HLA-B*4402 and B*4403 molecules. It competed nearly as efficiently as a tyrosinase peptide, which is recognized by CTL clones on HLAB*4402 or HLA-B*4403 melanoma cells (Brichard et al. 1995; Fig. 3). Peptides homologous to peptide MEVDPIGHLY, derived from the MAGE1, 2, 4, 6, and 12 genes, and containing the HLA-B44 binding motif, were also able to bind to HLA-B44 (data not shown).

The sequence of peptide MEVDPIGHLY includes that of the MAGE3.A1 peptide, EVDPIGHLY, which we knew to be processed in cells expressing MAGE3, since it is recognized by HLA-A1-restricted CTL on MAGE3+ melanomas (Gaugler et al. 1994). Moreover, peptide MEVDPIGHLY showed significant binding in vitro to purified soluble TAP1/TAP2 heterodimers (Fleischhauer et al. manuscript in preparation). Therefore anticipating that peptide MEVDPIGHLY may also be presented by cells expressing $M A G E 3$, we focused on this peptide, referred to below as MAGE3.B44.

Analysis of alanine-substituted variant peptides indicated that the side chain of the carboxyterminal tyrosine of nonamer MAGE3.A1 and decamer MAGE3.B44 was critical in anchoring these peptides into HLA-A1 and HLAB44 (Gaugler et al. 1994, and data not shown). But the other anchor residue appeared to be different for each 


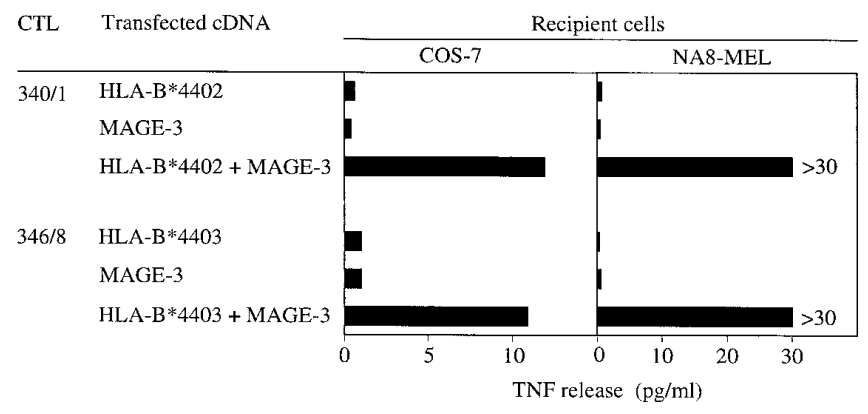

Fig. 4 Recognition of transfected cells expressing HLA-B44 and MAGE3 by MAGE3.B44-specific CTL clones. The MAGE3 and HLA-B*4403 cDNAs were cloned into expression plasmid pcDNAI/ Amp, and the HLA-B*4402 cDNA was cloned into expression plasmid pcDNA3. COS-7 (10000/well) and NA8-MEL (30000/well) cells were transfected using DEAE-dextran and liposomes, respectively. After $36 \mathrm{~h}$, CTL (3000/well) were added to the transfectants and after a further $20 \mathrm{~h}$ the concentration of TNF released in the medium was measured with the TNF-sensitive WEHI-164c13 cells

peptide: Asp in position 3 was critical for binding of the nonamer to HLA-A1, and Glu in position 2 for the decamer's binding to HLA-B44. The nonamer did not bind detectably to HLA-B*4402 molecules, but it bound to HLA-B*4403 about ten times less efficiently than the decamer. In addition to binding to HLA-A1 and B44, the nonamer bound also to HLA-A29 molecules, through residues in positions 2, 5, 8, and 9 (I. F. Luescher, manuscript in preparation). This type of peptide binding to different HLA molecules through different residues differs from the previously described "supermotifs" which allow peptide binding to different HLA molecules through the same main anchor residues (del Guercio et al. 1995; Sidney et al. 1995).

\section{Induction of CTL recognizing peptide MAGE3.B44}

Adherent PBMC were isolated from healthy donor LB816, whose HLA-type was HLA-B*4402. They were cultured for 7 days in the presence of GM-CSF and IL-4 in order to increase the proportion of dendritic cells (Romani et al. 1994; Sallusto and Lanzavecchia 1994). These cells were incubated with peptide MAGE3.B44 $(50 \mu \mathrm{M})$, irradiated, and used as stimulator cells in six cultures of $2 \times 10^{6} \mathrm{CD}^{+}$ blood $\mathrm{T}$ lymphocytes of the donor in medium containing IL-6 and IL-12. On days 7 and 14, the responder cells were restimulated with irradiated autologous PBMC incubated with the peptide in medium containing IL-2 and IL-7, and on day 20 the lytic activity was assessed on HLA-B*4402 lymphoblastoid B cells sensitized with peptide MAGE3.B44 (Fig. 1 A). Only one of the six populations of responder cells preferentially lysed the peptide-pulsed target cells. The same procedure was used to derive MAGE3.B44-specific lytic effectors from PBMC of the HLA-B*4403 healthy donor LB822. One of five populations of responder cells appeared to contain anti-peptide CTL (Fig. 1B). These results suggested that under these conditions the frequency of precursors of MAGE-3.B44specific CTL was of the order of $1 / 10^{7} \mathrm{CD}^{+}$lymphocytes.

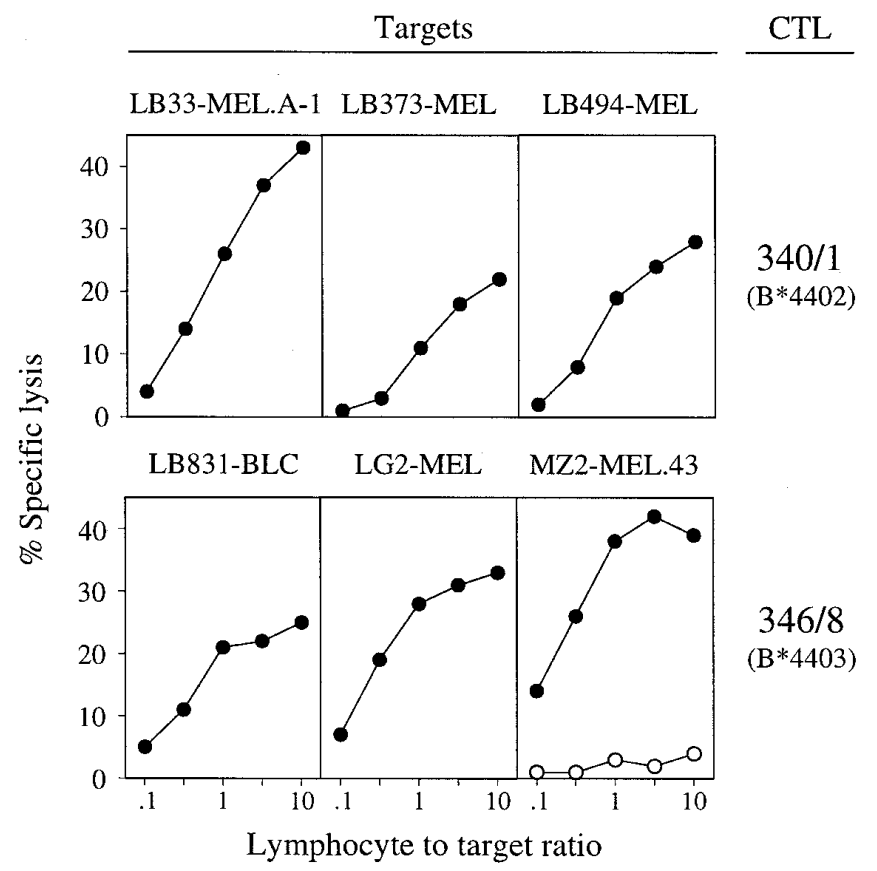

Fig. 5 Lytic activity of MAGE3.B44-specific CTL clones on HLAB44 tumor cell lines expressing MAGE-3. CTL clone 340/1, derived from the HLA-B*4402 donor, was tested against HLA-B*4402 tumor cells, and CTL clone 346/8, derived from the HLA-B*4403 donor, was tested against HLA-B*4403 tumor cells. Target cells included MAGE3+ melanoma cell lines, MZ2-MEL.61.2 cells which have lost expression of gene-MAGE-3 $(\bigcirc)$, and one MAGE3+ bladder carcinoma cell line. All target cells, except MZ2-MEL.43, MZ2-MEL.61.2 and LG2-MEL, were incubated over $48 \mathrm{~h}$ with IFN $\gamma$ (50 units/ml) prior to the lysis assay. Expression of HLA-B*4402, HLA-B*4403, and MAGE3 by the various target cells was tested by RT-PCR. Chromium release was measured after $5 \mathrm{~h}$

The lymphocytes of the two positive cultures were cloned by limiting dilution. CTL clone LB816-CTL-340/1 lysed HLA-B*4402 EBV-transformed B cells incubated with peptide MAGE3.B44. CTL clone LB822-CTL-346/8 recognized the MAGE3.B44 peptide presented by HLAB*4403 cells (Fig. 2). Half-maximal lysis was obtained at a peptide concentration of approximately $40 \mathrm{nM}$ for CTL 340/ 1 and $100 \mathrm{nM}$ for CTL 346/8.

The MAGE6-encoded peptide, which is homologous to the MAGE3.B44 peptide and differs from it only at position $9(\mathrm{~L} \rightarrow \mathrm{V})$, was not recognized by the MAGE3.B44-specific CTL clones, although this peptide bound efficiently to both HLA-B44 subtypes. The leucine residue in position 9 of peptide MAGE-3.B44 is therefore part of the epitope recognized by the receptors of the two CTL clones.

\section{Recognition by CTL of HLA-B44 cells expressing the MAGE3 gene}

To determine whether the MAGE3.B44 peptide was naturally presented by HLA-B44 on cells that expressed $M A G E 3$, COS-7 cells were co-transfected with MAGE3 and $H L A-B * 4402$ or $H L A-B * 4403$ cDNA clones. These 
cDNAs had been inserted into expression vectors carrying the SV40 origin of replication, which multiply in large numbers in COS-7 cells, because these cells express the SV40 T product (Gluzman 1981). The cells transfected with the two constructs stimulated TNF release by CTL clones $340 / 1$ and 346/8, whereas those transfected with HLA-B44 or MAGE3 alone did not (Fig. 4). Similar results were obtained when the melanoma cells NA8-MEL, which express neither $H L A-B 44$ nor $M A G E 3$, were cotransfected with $H L A-B 44$ and MAGE3 cDNA clones. Recognition of the MAGE3/HLA-B44 antigen therefore does not require the very high gene copy number present in COS-7 cells.

The two MAGE3.B44-specific CTL clones also efficiently lysed several HLA-B44 tumor cell lines which expressed the MAGE3 gene (Fig. 5). Tumor cell lines that did not express MAGE3 or HLA-B44 were not lysed by the CTL clones.

The MAGE3.B44 peptide may prove useful for specific immunization of HLA-B44 cancer patients. In several types of tumors, MAGE3 is the most frequently expressed $M A G E$ gene: $76 \%$ of metastatic melanomas (Brasseur et al. 1995), $48 \%$ of head and neck tumors, $35 \%$ of bladder carcinomas (Patard et al. 1995), 31\% of lung carcinomas (Weynants et al. 1994), $24 \%$ of sarcomas and $12 \%$ of breast cancers (Russo et al. 1995). The identification of a MAGE3/HLAB44 antigen increases the proportion of cancer patients eligible for immunization against MAGE-encoded antigens. With regard to metastatic melanoma, approximately $17 \%$ of caucasian patients should express this antigen, since $24 \%$ of individuals are $H L A-B 44$, and $76 \%$ of metastatic melanomas express the MAGE3 gene. In addition, $37 \%$ of patients express antigen MAGE-3/HLA-A2 and $20 \%$ express antigen MAGE3/HLA-A1. Around 53\% of metastatic melanoma patients express at least one of the MAGE3-encoded antigens.

Acknowledgments We thank Dr. C. Servis (Ludwig Institute, Lausanne) and Dr. J. Luchetti (Ludwig Institute, Brussels) for synthesis of peptides, and Ms. T. Aerts for expert technical assistance. The secretarial assistance of Ms. S. Khaoulali is gratefully acknowledged. We thank Dr. J.-C. Renauld for reviewing the manuscript, and Ms. A. Walker for her invaluable editorial help. This work was supported by the Belgian Programme on Interuniversity Poles of Attraction initiated by the Belgian State, Prime Minister's Office, Science Policy Programming, and by grants from the Association contre le Cancer, Brussels, Belgium, from the BIOMED1 programme of the European Community, and from the Fonds National de la Recherche Scientifique (grant TELEVIE), Brussels, Belgium, S. M. was supported by a fellowship from the Italian Association for Cancer Research (AIRC). K. F. is a recipient of a fellowship from the Telethon Gene Therapy Program, Italy, and from the Antonio Castelnuovo Foundation, Italy. J. H. and P. C. are Research Assistant and Research Associate with the Fonds National de la Recherche Scientifique, Brussels, Belgium.

\section{References}

Atherton, E., Logan, C. J., and Sheppard, R. C. Peptide synthesis. Part 2. Procedures for solid phase synthesis using N $\alpha$-fluorenylmethysoxycarbamylamino-acid on polymide supports. Synthesis of substance P and of acyl carrier protein 65-74 decapeptide. J Chem Soc Lond Perkin Trans I: 538, 1981
Boon, T., Cerottini, J.-C., Van den Eynde, B., van der Bruggen, P., and Van Pel, A. Tumor antigens recognized by T lymphocytes. Annu Rev Immunol 12: 337-365, 1994

Brasseur, F., Marchand, M., Vanwijck, R., Hérin, M., Lethé, B., Chomez, P., and Boon, T. Human gene MAGE-1, which codes for a tumor rejection antigen, is expressed by some breast tumors. Int J Cancer 52: 839-841, 1992

Brasseur, F., Rimoldi, D., Liénard, D., Lethé, B., Carrel, S., Arienti, F., Suter, L., Vanwijck, R., Bourlond, A., Humblet, Y., Vacca, A., Conese, M., Lahaye, T., Degiovanni, G., Deraemaecker, R., Beauduin, M., Sastre, X., Salamon, E., Dréno, B., Jäger, E., Knuth, A., Chevreau, C., Suciu, S., Lachapelle, M., Pouillart, P., Parmiani, G., Lejeune, F., Cerottini, J.-C., Boon, T., and Marchand, M. Expression of MAGE genes in primary and metastatic cutaneous melanoma. Int J Cancer 63: 375-380, 1995

Brichard, V. G., Herman, J., Van Pel, A., Wildmann, C., Gaugler, B., Wölfel, T., Boon, T., and Lethé, B. A tyrosinase nonapeptide presented by HLA-B44 is recognized on a human melanoma by autologous cytolytic T lymphocytes. Eur J Immunol 26: 224-230, 1996

Burrows, S. R., Misko, I. S., Sculley, T. B., Schmidt, C., and Moss, D. J. An Epstein-Barr virus-specific cytotoxic T-cell epitope present on A- and B-type transformants. J Virol 64: 3974-3976, 1990

Buseyne, F., McChesney, M., Porrot, F., Kovarik, S., Guy, B., and Rivière, Y. Gag-specific cytotoxic T lymphocytes from human immunodeficiency virus type 1-infected individuals: gag epitopes are clustered in three regions of the p24gag protein. J Virol 67: 694-702, 1993

Celis, E., Tsai, V., Crimi, C., DeMars, R., Wentworth, P. A., Chesnut, R. W., Grey, H. M., Sette, A., and Serra, H. M. Induction of antitumor cytotoxic $\mathrm{T}$ lymphocytes in normal humans using primary cultures and synthetic peptide epitopes. Proc Natl Acad Sci USA 91: 2105-2109, 1994

Coulie, P. G., Lehmann, F., Lethé, B., Herman, J., Lurquin, C., Andrawiss, M., and Boon, T. A mutated intron sequence codes for an antigenic peptide recognized by cytolytic $\mathrm{T}$ lymphocytes on a human melanoma. Proc Natl Acad Sci USA 92: 7976-7980, 1995

De Plaen, E., Arden, K., Traversari, C., Gaforio, J. J., Szikora, J.-P., De Smet, C., Brasseur, F., van der Bruggen, P., Lethé, B., Lurquin, C., Brasseur, R., Chomez, P., De Backer, O., Cavenee, W., and Boon, T. Structure, chromosomal localization and expression of twelve genes of the MAGE family. Immunogenetics 40: 360-369, 1994

Del Guercio, M.-F., Sidney, J., Hermanson, G., Perez, C., Grey, H. M., Kubo, R. T., and Sette, A. Binding of a peptide antigen to multiple HLA alleles allows definition of an A2-like supertype. J Immunol 154: 685-693, 1995

DiBrino, M., Parker, K. C., Margulies, D. H., Shiloach, J., Turner, R. V., Biddison, W. E., and Coligan, J. E. Identification of the peptide binding motif for HLA-B44, one of the most common HLA-B alleles in the Caucasian population. Biochemistry 34: 10130-10138, 1995

Espevik, T. and Nissen-Meyer, J. A highly sensitive cell line, WEHI 164 clone 13, for measuring cytotoxic factor/tumor necrosis factor from human monocytes. J Immunol Methods 95: 99-105, 1986

Fleischhauer, K., Kernan, N. A., O’Reilly, R. J., Dupont, B., and Yang, $\mathrm{S}$. Y. Bone marrow-allograft rejection by $\mathrm{T}$ lymphocytes recognizing a single amino acid difference in HLA-B44. N Engl J Med 323: $1818-1822,1990$

Fleischhauer, K., Kernan, N. A., Dupont, B., and Yang, S. Y. The two major subtypes of HLA-B44 differ for a single amino acid in codon 156. Tissue Antigens 37: 133-137, 1991

Fleischhauer, K., Avila, D., Vilbois, F., Traversari, C., Bordignon, C., and Wallny, $\mathrm{H}$. Characterization of natural peptide ligands for HLA-B*4402 and HLA-B*4403: implications for peptide involvement in allorecognition of a single amino acid change in the HLAB44 heavy chain. Tissue Antigens 44: 311-7317, 1994

Gaugler, B., Van den Eynde, B., van der Bruggen, P., Romero, P., Gaforio, J. J., De Plaen, E., Lethé, B., Brasseur, F., and Boon, T. Human gene MAGE-3 codes for an antigen recognized on a melanoma by autologous cytolytic T lymphocytes. J Exp Med 179: 921-930, 1994 
Gluzman, Y. SV40-transformed simian cells support the replication of early SV40 mutants. Cell 23: 175-182, 1981

Imanishi, T., Akaza, T., Kimura, A., Tokunaga, K., and Gojobori, T. Allele and haplotype frequencies for HLA and complement loci in various ethnic groups. In K. Tsuji, M. Aizawa, and T. Sasazuki (eds.): HLA 1991, Vol 1, XIth International Histocompatibility Workshop and Conference, Oxford University Press, Oxford, 1991

Keever, C. A., Leong, N., Cunningham, I., Copelan, E. A., Avalos, B. R., Klein, J., Kapoor, N., Adams, P. W., Orosz, C. G., Tutschka, P. J., and Baxter-Lowe, L. A. HLA-B44-directed cytotoxic T cells associated with acute graft-versus-host disease following unrelated bone marrow transplantation. Bone Marrow Transplant 14: $137-145,1994$

Khanna, R., Burrows, S. R., Kurilla, M. G., Jacob, C. A., Misko, I. S., Sculley, T. B., Kieff, E., and Moss, D. J. Localization of EpsteinBarr virus cytotoxic $\mathrm{T}$ cell epitopes using recombinant vaccinia: implications for vaccine development. J Exp Med 176: 169-176, 1992

Kita, H., Moriyama, T., Kaneko, T., Harase, I., Nomura, M., Miura, H., Nakamura, I., Yazaki, Y., and Imawari, M. HLA-B44-restricted cytotoxic $\mathrm{T}$ lymphocytes recognizing an epitope on hepatitis $\mathrm{C}$ virus nucleocapsid protein. Hepatology 18: 1039-1044, 1993

Lee, T. D. Distributions of HLA antigens. In J. Lee (ed.): The HLA System. A New Approach, pp. 141-178, Springer, Berlin Heidelberg, 1990

Lehmann, F., Marchand, M., Hainaut, P., Pouillart, P., Sastre, X., Ikeda, H., Boon, T., and Coulie, P. G. Differences in the antigens recognized by cytolytic $\mathrm{T}$ cells on two successive metastases of a melanoma patient are consistent with immune selection. Eur J Immunol 25: 340-347, 1995

Mikamo, S. A novel method for the purification of sheep red cell rosetting lymphocytes. J Immunol Methods 107: 189-196, 1988

Muscatelli, F., Walker, A. P., De Plaen, E., Stafford, A. N., and Monaco, A. P. Isolation and characterisation of a new MAGE gene family in the Xp21.3 region. Proc Natl Acad Sci USA, 92: 4987-4991, 1995

Patard, J.-J., Brasseur, F., Gil-Diez, S., Radvanyi, F., Marchand, M., François, P., Abi Aad, A., Van Cangh, P., Abbou, C. C., Chopin, D., and Boon, T. Expression of MAGE genes in transitional-cell carcinomas of the urinary bladder. Int J Cancer 64: 60-64, 1995

Petersdorf, E. W., Setoda, T., Smith, A. G., and Hansen, J. A. Analysis of HLA-B*44 alleles encoded on extended HLA haplotypes by direct automated sequencing. Tissue Antigens 44: 211-216, 1994

Romani, N., Gruner, S., Brang, D., Kämpgen, E., Lenz, A., Trockenbacher, B., Konwalinka, G., Fritsch, P. O., Steinman, R. M., and Schuler, G. Proliferating dendritic cell progenitors in human blood. J Exp Med 180: 83-93, 1994
Russo, V., Traversari, C., Verrecchia, A., Mottolese, M., Natali, P. G., and Bordignon, C.: Expression of the MAGE gene family in primary and metastatic human breast cancer: implications for tumor antigen-specific immunotherapy. Int $J$ Cancer 64: 216-221, 1995

Sallusto, F. and Lanzavecchia, A. Efficient presentation of soluble antigen by cultured human dendritic cells is maintained by granulocyte/macrophage colony-stimulating factor plus interleukin 4 and downregulated by tumor necrosis factor $\alpha$. J Exp Med 179: 1109-1118, 1994

Seed, B. and Aruffo, A. Molecular cloning of the CD2 antigen, the Tcell erythrocyte receptor, by a rapid immunoselection procedure. Proc Natl Acad Sci USA 84: 3365-3369, 1987

Sidney, J., del Guercio, M.-F., Southwood, S., Engelhard, V. H., Appella, E., Rammensee, H.-G., Falk, K., Rötzschke, O., Takiguchi, M., Kubo, R. T., Grey, H. M., and Sette, A. Several HLA alleles share overlapping peptide specificities. J Immunol 154: 247-259, 1995

Storkus, W. J., Howell, D. N., Salter, R. D., Dawson, J. R., and Cresswell, P. NK susceptibility varies inversely with target cell class I HLA antigen expression. J Immunol 138: 1657-1659, 1987

Traversari, C., van der Bruggen, P., Luescher, I. F., Lurquin, C., Chomez, P., Van Pel, A., De Plaen, E., Amar-Costesec, A., and Boon, T. A nonapeptide encoded by human gene MAGE-1 is recognized on HLA-A1 by cytolytic $\mathrm{T}$ lymphocytes directed against tumor antigen MZ2-E. J Exp Med 176: 1453-1457, 1992

Van der Bruggen, P., Bastin, J., Gajewski, T., Coulie, P. G., Boël, P., De Smet, C., Traversari, C., Townsend, A., and Boon, T. A peptide encoded by human gene MAGE-3 and presented by HLA-A2 induces cytolytic $\mathrm{T}$ lymphocytes that recognize tumor cells expressing MAGE-3. Eur J Immunol 24: 3038-3043, 1994

Van der Bruggen, P., Traversari, C., Chomez, P., Lurquin, C., De Plaen, E., Van den Eynde, B., Knuth, A., and Boon, T. A gene encoding an antigen recognized by cytolytic $\mathrm{T}$ lymphocytes on a human melanoma. Science 254: 1643-1647, 1991

Weynants, P., Lethé, B., Brasseur, F., Marchand, M., and Boon, T. Expression of MAGE genes by non-small-cell lung carcinomas. Int J Cancer 56: 826-829, 1994

Yao, Z., Keller, E., Scholz, S., McNicholas, A., Volgger, A., and Albert, A. Identification of two major HLA-B44 subtypes and a novel B44 sequence (B*4404). Hum Immunol 42: 54-60, 1995 a

Yao, Z., Lattermann, A., Volgger, A., McNicholas, A., Mueller-Eckhardt, G., and Albert, E. A new HLA-B44 subtype, B*4406, differing in exon 2. Immunogenetics 41: 387, $1995 \mathrm{~b}$

Yao, Z., Volgger, A., Scholz, S., Bönisch, J., and Albert, E. D. Nucleotide sequence of a novel $H L A-B 44$ subtype $(B * 4405)$. Immunogenetics 40: 310, 1994 